anthropology \& materialism

\section{Anthropology \& Materialism}

A Journal of Social Research

$3 \mid 2016$

Utopia: The Elsewhere and The Otherwise

\title{
Worlds Not Yet in Being
}

Reconciling Anthropology and Utopianism

Des mondes qui n'existent pas encore. Réconcilier l'anthropologie et l'utopisme

Mundos que aún no existen. Reconciliando la antropología y el utopismo

\section{Martin Hébert}

\section{OpenEdition}

\section{Journals}

Electronic version

URL: http://journals.openedition.org/am/604

DOI: $10.4000 / a m .604$

ISSN: 2364-0480

Publisher:

CETCOPRA, CRASSH - Center for Research in the Arts Social Sciences and Humanities, Fakultät

Gestaltung - Universität der Künste Berlin

Electronic reference

Martin Hébert, « Worlds Not Yet in Being », Anthropology \& Materialism [Online], $3 \mid$ 2016, Online since 06 December 2016, connection on 20 April 2019. URL : http://journals.openedition.org/am/604 ; DOI : 10.4000/am.604

This text was automatically generated on 20 April 2019.

Tous droits réservés 


\title{
Worlds Not Yet in Being
}

\author{
Reconciling Anthropology and Utopianism \\ Des mondes qui n'existent pas encore. Réconcilier l'anthropologie et l'utopisme \\ Mundos que aún no existen. Reconciliando la antropología y el utopismo
}

\section{Martin Hébert}

\section{Introduction}

1 This article seeks to further our understanding of how the concept of utopia applies to contemporary critical anthropology. The proposal to link utopia and critical social theory is not new. It draws strongly from Karl Mannheim's famous work, Ideology and Utopia (1985 [1929]), and its contemporary echoes in various corners of social theory. However, saying that anthropology has failed to follow up on proposals to make utopia relevant to social sciences would, unfortunately, still be an understatement. Without doubt anthropologists produced important ethnographies of utopian intentional communities (Spiro 1957, 2004; Love Brown 2001; Price, Nonini and Fox Tree 2008; Lockyer and Veteto 2013), and some of them have employed utopian theory emerging from Mannheim's or Ernst Bloch's seminal works (Cooper 2014). However, in anthropology a lot of work still has to be done to explore the interpretative potential of the concept of utopia in contexts where the family resemblance between field and utopia is less obvious (Uhlenbruch 2015). Scholars within the discipline have also called for the 'repatriation' of anthropology's utopian potentials. Most notably, Marcus and Fischer (1986: 136) argue that the juxtaposition of diverse social and cultural possibilities expressed in a common world is implicit to the ethnographic method itself. For these authors, thinking through differences and encounters bears the potential for creating a utopian "breech" within naturalised social orders. David Graeber also writes about the utopian potential of ethnography, arguing that experiences, understood as ideas lived in the field, can be "offered back" to communities as utopian possibilities (Graeber 2004: 11-12).

Much could be said about the unease anthropology shows in respect to utopia as a concept and mode of thinking. In part, this discomfort seems to spring from the roots 
shared by both discourses - anthropology and literary utopia - who count exotic travel narratives among their genealogy (Marouby 1990; Rhiannon 1999; Rubiés 2007). As it aspired to establish its scientific credentials, anthropology has tried to define itself against this heritage of exotic writings, at times struggling with the "temptation of fiction" (Meunier 1992: 278), which literary utopias have embraced. Another reason for the anthropologists' reluctance to draw from utopian theory is the worry that the concept of utopia is so intimately linked to Western modernity that it is all but unusable in other contexts. Jean Servier (1991), for instance, calls utopia the "adventure of the West". Others highlight the fact that utopianism has often served as the ideological framework for settler colonialism and forced religious conversion (Mohawk 2000; Green 2004; Berquist Soule 2014). To address this criticism seriously, my first task in this paper is to describe more precisely which branch of utopian theory I will refer to, and why it can be productive. I will then open a dialogue between these ideas and the empirical material drawn from the Indigenous politics in the State of Chiapas, Mexico. Rather than adding to the considerable amount of empirical studies dealing with the Indigenous communities of Chiapas and the Zapatista movement, my goal is to use existing material as well as my own field experiences in the region to support the claim that utopia and its allied concept of hope, understood here as social and political hope for earthly change, can play a productive and more central role in anthropological theory in general, and in comparative anthropology in particular.

Outside the field of anthropology, commentators were never shy to use the vocabulary of utopia to talk about Indigenous lives and struggles in Chiapas. One of the major works of political history about the region is Antonio García de León's Resistencia y utopia (1985), published almost a decade before the Zapatista uprising. Since then, numerous activists, journalists and researchers have used the concept of utopia explicitly to frame their understanding of the dynamics of this complex movement, a movement that encompasses local land struggles as much as global anti-capitalist networks (García Quintanilla 1994; Miranda Ocampo 1995; López Monjardín 1998; Hernández Castillo 1999; Mouterde 2002). An important collection of academic texts about Indigenous struggles in Chiapas (Rus et al. 2003) has the title Mayan Lives, Mayan Utopias. Most of the contributors to this volume are anthropologists, and it is telling that it is a political scientist who uses the concept of utopia most explicitly. She proposes that reclaiming a utopian mode of discourse in Indigenous communities is a sign of political agency:

For most of the almost five hundred years since [the Conquest], however, America's indigenous people have not been permitted to imagine, much less implement, their own ideas about what a better society might be like. What has changed in the present generation, most strikingly in Chiapas, is that Indians have asserted the right to dream of utopias, not because their societies are utopian, but because they - like all people everywhere - have the right to reflect on and imagine alternative futures. (Mattiace 2003 : 185-186)

Indigenous struggles in Chiapas provided fertile grounds to think about politics through the lens of utopia. However, work still has to be done in the intersection of these studies and anthropological theory. As I will argue in the final section of this essay, for anthropology the concrete benefits of a perspective centred on hope and political imagination is that it helps us to think beyond the "suffering subject", which is often at the centre of ethnographies concerned with power relations. Utopia also has the potential to draw our attention toward the possibilities, dynamism and political relevance of worlds not yet in being. 
Before moving on, it is important to mention that utopia and its parent concepts do not always receive the same treatment. For instance, the anthropologists' unease with the vocabulary of utopia led some of them to eschew the term while still recognising the centrality of hope and political imagination within the Zapatista movement:

While I do not deny the power and significance of utopian imaginations and aspirations, I contend that the phenomenon of Zapatismo's resonance, the political imaginations it has provoked and entered in dialogue with, and the concrete political practices that have emerged out of them cannot be appropriately characterized as 'utopian'. Rather than signifying a yearning for utopia, literally 'no place', the political imaginations I trace here emerge, are situated in, and are inspired by a multitude of places. (Khasnabish $2008: 156-157)$

This critique brings us back to the importance of specifying what aspect of utopian theory is productive for anthropology. Obviously, in a discipline whose central method involves fieldwork and "being there", adhering to the premise that utopia involves a no-place, as is the case with literary utopias, is problematic. Even more so is the notion that utopia involves detailed and set plans for a eu-topia, an idealised "good place". These understandings of the term undercut the very possibility of situating and grounding ethnographic thinking. However, closing the discussion about utopia and anthropology at this point would be premature. Utopian theory has more to offer than reflections about disembodied social blueprints. Thus, the next section will examine a particularly fruitful link between utopian theories and the social sciences: focusing not on the content or form of utopia, but rather on its concrete articulations with, and opposition to, a given social order. Such readings of utopia as a social force were proposed by "heretic Marxists" (Löwy 1996: 5) like Ernst Bloch, Raymond Williams or Darko Suvin, materialists who took symbolic productions as sui generis objects of studies, not as epiphenomena reducible to an underlying, supposedly more fundamental, economic structure. The work of Karl Mannheim will serve to map some of this territory, spelling out its implications for anthropological work.

\section{Utopian Mentality onward}

7 Karl Mannheim breaks with two important interpretations of utopia. By defining utopia as a literary tradition, a number of historical syntheses published in the1920s had worked with a rather strict template, classifying texts mostly on the basis of their formal resemblance to Thomas More's Utopia (Firestone 1924; Dermenghem 1927). However, Mannheim was not interested in utopian textual productions, but in what he termed, in a more diffused way, "utopian mentality".

8 Although Mannheim was not the first author to propose a broader view of what should be considered as "utopian thought" (Hertzler 1923), he certainly was among those who articulated most explicitly at the time the concrete political implications of utopianism. In this, we can find his second significant break with the common views of utopia at the time: he gave a positive connotation to the term. Most relevant in this respect is that Mannheim distances himself from Engels' influential reading of "utopian socialism" ultimately as a futile philosophical exercise. For the author of Socialism: Utopian and Scientific, trying to invent goals and means for social change rather than discovering them scientifically in the facts of material production and exchange was a sign of theoretical immaturity (Engels 1908 [1880]: 94). Mannheim agrees with Engels that complete and 
polished utopias drafted only in imagination lead to poor politics. However, drawing from a number of contemporaries, Mannheim recognises that utopianism is much more than the mere production of abstractions; it can also be a unique social force with very material implications. By putting emphasis on "inspiration" as a motivating power of collective struggles, he is very much in line with Ernst Bloch's Thomas Münzer (1964 [1921]). He also recognises the affiliation of his ideas with Doren's (1927) discussion of the role "yearning" plays in politics. Mannheim also draws from Joyce Oramel Hertzler's redefinition of utopianism. Whereas most usages of the term up to that point were pejorative, equating utopianism with ridiculous proposals, and seeing the "stamp of Utopianism" as a mark that would render the acceptance of ideas hopeless (Bentham 1827: 69), Hertzler proposes a new definition of the term. For her, utopianism is best understood as a "conception of social improvement either by ideas and ideals themselves or embodied in definite agencies of social change" (Hertzler 1923: 2-3). Clearly, Mannheim does not favour the notion that ideas could affect social change by themselves, but coherent with his Blochian influences he adheres to the view that being embodied in action is precisely how "situationally transcendent" ideas become utopian, and thus relevant to politics (Mannheim 1985 [1929]: 193).

9 Although literary scholars criticised the loss of conceptual clarity caused by the broadening of the term "utopia" (Sargent 1979), going so far as to claim that this vagueness prevents utopia from being a concept (Raulet 1992), it is undeniable that Mannheim's understanding of the utopian mentality as being rooted in subversive experience, thought and practice had a significant influence on social theory's treatment of power and social change. The notion of the "utopian mentality" and Bloch's idea of "utopian imagination" (1995 [1939]) were at the root of a lot of scholarship that dealt with utopia as a social force. The interest came in waves, most notably during the "utopian years" between 1968 and 1978 (Ansart 1977; Delanoi 1990; Buckley and Violeau 2011) and during the mid-1980s (Goodwin and Taylor 1982; Ricoeur 1986; Moylan 1986), and has experienced a significant increase since the mid-1990s, again within Marxist traditions that by now have become less and less marginal (Wright 2010). For some of these scholars, documenting, understanding and advocating the place of hope, yearnings, desires in local and global praxis became key for our common future. In the face of a profound structural crisis within the global capitalist political economy, and of ecological problems that simply cannot be ignored anymore, thinking about radically different possibilities has often come to be seen not as fanciful or idealistic but rather, on the contrary, as the only realistic approach to dignified human survival (Fuller 1969, Dumont 1973, Wallerstein 1998). For others, caught in a globalised capitalist system that accumulates massive contradictions, but does not collapse, that presents itself as the only possible world, but bears many similarities with a dystopia, the expression of the utopian impulse, the production of "other worlds" and possibilities, has become synonymous with the expression of human dignity (Abensour 2013), and the reclaiming of an intellectual optimism capable of responding to the multifaceted violence of globalisation (Harvey 2000).

The Zapatista movement played a significant role in this constellation of renewed utopian desire. It is not a coincidence that many examples I will look at in the following sections are taken from the early years of the Zapatista movement. The mid-1990s have been a turning point for a renewed practical and theoretical interest in utopianism. In the wake of the proclamation of the "end of history" (Fukuyama 1992) and the collapse of several 
experiments in socialism, be it the fall of the Berlin Wall or the demobilization of many revolutionary movements in Latin America in the early 1990s, the "postmodern guerilla" of the Zapatista movement appeared as a reinvention of subaltern politics. Instead of following the path of other movements that were caught for decades in a spiral of violent confrontations with the State, for instance in Guatemala, El Salvador, Colombia and Peru, the Ejercito Zapatista de Liberación Nacional (EZLN) changed its strategy after twelve days of combat, and quickly reoriented its efforts to build alliances with the national and international civil society. This meant organising a number of ambitious forums where a wide diversity of groups concerned with issues of social and environmental justice met to create what was called an "International of Hope". I will return to this in the next section. At this point, however, I would like to emphasise that in a moment of generalised pessimism regarding the prospects to offer a credible alternative to what appeared as the steamroller of neoliberal globalisation, the Zapatistas created significant utopian momentum. Of course, the actions of the Zapatistas must be placed within the context of the anti-globalisation or altermondialiste movements that emerged during that time and began to protest against IMF, World Bank and G7 summits, as well as the global Indigenous movements that coalesced around the $500^{\text {th }}$ anniversary of the Europeans' arrival in the Americas and the Rio Summit of 1992. However, in 1994 and 1995 few were as insistent as the Zapatistas on proposing concrete and practical alternatives, hence the proliferation of associations between the Zapatistas and utopianism

11 This excursion from the work of Karl Mannheim to the Zapatistas engaging in utopian thinking and practice in the jungles of the Selva lacandona, indicates that both social theory, as it has developed since the 1920s, and the interlocutors I encountered during my fieldwork invite anthropologists to take utopia seriously. During my first research trip in Chiapas, living in a Tzeltal community of the Selva Lacandona in 1996, I became acquainted with this utopianism as it was articulated on the local level. Most notably, an elder member of the village in which I stayed described to me the existence of a large plot of land prepared by the Zapatistas deep in the jungle, ready for the villagers who might flee the poor living conditions and the militarisation that afflicted existing communities. In his brief narrative, he mentioned that local Tzeltales were learning new skills that would be useful to live in their new "city" (ciudad), as the man called that enigmatic place. Supposedly, the villagers were now learning to bake bread, a key feature of their plan. At the time, I transcribed the brief narrative in my notes, but intuitively interpreted it as a literary utopia. Given the level of militarisation in the region, the density of the population, and the State-protected nearby conservation areas, it seemed unlikely that such a relocation plan would be feasible. I saw this narrative as the echo of an earlier discourse heavily influenced by a local appropriation of the book of Exodus, which had played a well-documented role in the migration of Tzeltales from the Highlands of Chiapas to the Selva lacandona between the late 19th and the mid-20th Centuries (Legorreta Díaz 1998).

12 As it turned out, my interpretation of this local utopianism was wrong. Although there was no such thing as the myriad hectares of Cokaygne that were described to me, some families from the Selva lacandona were indeed in the process of occupying land within the nearby biological reserve of the Montes Azules, which has more than 300,000 hectares of pristine tropical forest. When I was able to visit some of these new communities in 2010, it was striking to see that the families who moved to the preserve had significantly changed some of their production processes, including the replacement of the millennia- 
old slash-and-burn agriculture by a method that involved slashing the forest and leaving the cut vegetation on the ground to compost. They also built special adobe ovens to reduce the need for firewood, ovens that were very much suited to the fabrication of bread, just as my interlocutor alluded to 14 years earlier.

This anecdote is relevant to the present discussion because it shows that even though utopianism was very much at the core of the research I was conducting, the tendency was still to try and find it in the past, on the path leading to the present, rather than fully recognising utopia as a force that fuels change and is oriented toward the future. Interestingly enough, this perspective can also be found in other anthropological studies of the political imagination of contemporary Chiapanecan Maya groups in general, and in anthropological studies of the Zapatistas in particular (Matamoros Ponce 1998). Gary Gossen, one of the foremost authorities on the ethnography of the Tzotziles (another Mayan group that was involved in the Zapatista uprising), provides his own reading of the continuities between traditional Maya worldview and the Zapatistas' relationship to the exercise of political volition and planned social change. For him, Mesoamerican thought presents an "extrasomatic, coessential, nonlocal nexus of causality and destiny" (Gossen 1999: 244). This reading reflects what is perceived as "deep skepticism about individual automonomy" among the Mayas (Ibid.: 242). This implies that the community is the relevant "embodiment" of utopian ideas. In this light, if we look at a political process from within the community, "destiny", as Gossen terms it, meaning the emergent nature of Indigenous identities and projects, becomes a more operational concept than "future". Indeed, as long as it maintains solidarity, the community will have a common destiny brought about in a manner that will become clear retrospectively, while if local political is seen to proceed praxis by visions of how things could be, then the necessarily numerous and conflicting hopes and envisioned futures can become divisive and disrupt the harmony ideology documented in many Mesoamerican ethnographies (for example, Nader 1991, Hébert 2001). From this perspective, it seems that the underlying assumptions I observed in my own work and in the work of others working in the same region reflects a context in which explicit expressions of political volition by social groups that do not encompass the whole community are not read as utopianism, but rather as factionalism, or perhaps, as in my narrative about the founding of a new community in the jungle, as the mere fantasy of one person.

The anthropological relevance of the concept of utopia seems to increase as we move away from intra-community dynamics and look at broader contexts, especially at oppositional contexts where diverse actors are involved. An interesting contribution in this respect is the idea of "life projects" (Blaser, Feit, McRae 2004). Perhaps as "utopia" was presented as a counterpoint to "ideology" by Mannheim, life projects have been proposed as a conceptual counterpoint to the "development projects" that intrude in so many Indigenous territories today. As a combination of life and struggle, situated in a lived space, but also manifested as expression of Indigenous difference within broad transnational networks, these life projects generally stand as alternatives to neoliberal development. According to Blaser, they emerge from "densely and uniquely woven 'threads' of landscapes, memories, expectations and desires" (2004: 26). This characterisation captures the importance of the common "destiny" noted earlier, which can be seen as emerging from landscape and memory, from the place inhabited, and from the group's common historical situation. However, taking into account expectations and desires as dimensions of Indigenous agency and as vital threads of life projects creates an 
interesting space to address the problems associated with explicit political volition within the Mesoamerican thought discussed by Gossen. Given the emergency, if not outright violence created by developmentalist or extractivist pressures, the expression of life projects often gets reduced to the immediate will to preserve the territory and the existence of the community.

Given the fact that the concept of life projects has mostly been used in such high-pressure contexts, it seems that the more future-oriented aspects of expectations and desires, not to mention the expression of hopes, took on a somewhat secondary role in the application of the concept of life projects. This is consistent with the heritage of anthropology, which was often concerned with issues of sociocultural reproduction, in-group harmony, ethnic persistence, political survival and resilience of suffering subjects. The discipline paid much less attention to the "hoping subjects". Critical anthropology pays close attention to power inequalities, domination, exclusion, marginality, violence and many other vectors of suffering. Since the anthropological studies of the colonial situation's political economy in the mid-1950s (Balandier 1951; Stewart et al. 1956), critical anthropology has been focusing on domination and resistance (in the form of adaptation and resilience) for over six decades now. Often, these parameters have guided the anthropologists' comparative work. It is not the purpose of this text to question this approach. Its contributions to our thinking about social justice are enormous and still much needed. However, addressing the relative neglect of the "hoping subject", of the desires and intentional acts of political imagination that ethnography reveals to us, can help delineating how the concept of utopia - defined, following Mannheim, as a social force can contribute to anthropological theory.

In the next and final section, I will examine the Zapatistas' call for the creation of an "International of Hope", and discuss how it relates to the proposals to mobilise the concepts of hope and utopia in anthropology. This section will take on a project recently proposed by Joel Robbins (2013), looking at how this proposal could contribute to a comparative anthropology centred on the hoping subject.

\section{Utopia and critical anthropology}

17 With respect to Indigenous Mesoamerica, political encounters at different social scales can revolve around different modes of what Ernst Bloch called anticipatory consciousness (1995 [1939]). Within a given community, as described by Gossen, this consciousness can be understood as a common destiny, driven, one could add, by the duty to further the project of the ancestors by means of a daily lucha or struggle (Nash 1971; Hébert 2001). When confronted with site specific modernist development projects, this anticipatory consciousness is probably best described by the idea of life projects, which emphasises the hope of persistence in modes of being besieged by epistemic, structural and direct violence as well as desires grounded in places and memories. But as national and global networks of resistance are formed, scaled up, and necessarily become more heterogeneous, it might become relevant to distinguish between life projects and political projects. Discussing the Proceso de comunidades negras (PCN), an afro-colombian movement, Arturo Escobar introduces this distinction in the following manner:

There are aspects of this dense networking, however, that have remained intractable and underdiscussed; it involves much work by activists which is both inward- and outward- oriented and an articulation between both kinds of work; 
PCN activists indeed speak of work that needs to take place para adentro (directed toward the inside, a critical reflexive work), and hacia afuera (outward and actionoriented, e.g., in relation to the state [...]). From the most intimate practices on a day-to-day basis and the explicit attempts to draft a stable identity to the internationally oriented actions, this work of articulation is always going on. (Escobar $2008: 262$ )

18 My own observations in the Selva lacandona align with this reading. The ways in which movements, Zapatista or otherwise, are lived and understood locally are quite distinct from the ways in which they are incarnated in regional, national or international forums. A Tzletal community organiser, one of the many people that nevertheless keep these scales interconnected, describes in a conversation how at times the movement "took the shape" of civil society ("nos componemos en sociedad civil"). This was the case, for example, during the meetings in Mexico City, held in preparation of the Foro social de los Montes Azules of 2010. Activists from many international and national organisations were present at this event. However, organizing as part of civil society was seen only as one moment of the struggle, necessary but not sufficient. The day-to-day work of preserving the rights of Indigenous communities established within the Montes Azules biological reserve, he insisted, was carried out by "verdaderos hermanos", Tzeltales with significant ties and moral obligations to the communities to which they belonged (Hébert 2012: 218). In this sense, the political project pursued by participation in civil society was distinct from, although entwined with, local life projects.

19 If an analytical distinction is made between life projects and political projects, it seems relevant to also distinguish between the kinds of anticipatory consciousness that drive them. Since the work of Mannheim, utopia resonates well with the type of consciousness and type of political projects that I am referring to. The final words of the final declaration of the Foro social de los Montes Azules (2010) illustrate well the general tone of this discourse: "Our strategies will seek to articulate the political struggle with judicial defense, sustainable management of goods provided by nature, and the construction of projects fostering the good life (buen vivir)." General principles are affirmed (Escobar 2008: 262-263), but specific strategies are presented as being necessarily plural. The reference to a general category grouping many projects of buen vivir has the semantic openness and the yearning, the drive for something else, the "not-yet-being" that Bloch associated with the utopian imagination. To put it concisely, life projects seem mostly concerned with the expression of modes of being or existing worlds (Blaser 2013), while utopia underscores the hope for the not-yet-being. Both cases involve an ontological conflict, an opposition to dominant discourses, subjectivities and ideologies, but if utopia has a particularity, it is that it is concerned with the conflict between what is and what is not (yet).

20 It is worth noting that the declaration of the Foro social de los Montes Azules, as numerous other programmatic documents produced by Indigenous movements in the Selva lacandona such as the Zapatistas' Women's Revolutionary Laws or the six Declarations of the Selva lacandona, lend themselves to textual and discourse analysis (Saumier 2001; Montesano Montessori 2011; Ochoa 2013). This indicates that although our discussion has moved away significantly from references to literary utopias and detailed blueprints of social transformation, the utopian impulse at the heart of anti-hegemonic movements can hardly be said to be devoid of specific content. Even the more abstract calls for utopian rupture, such as the Zapatistas ¡Ya Basta! or the World Social Forum's "Another World is Possible", connote the end of one world, and the futures open to our existence 
beyond it, and therefore cannot exist socially as only "empty forms" communicating an impulse but no content (Marder and Vieira 2011: 35-36 ). Programmatic documents produced in broad forums specify the general principles on which this new world will be built. For instance, legal terminology pervades in these documents. The final declaration of the Foro social de los Montes Azules speaks of the rights to life, to human security and to self-determination, that belong to the communities established without legal title within the boundaries of the natural reserve. These are hardly any specific local life projects. Rather, they pertain to global political projects of human and Indigenous rights, which themselves can be situated within the utopian tradition (Moyn 2012; Habermas 2010). The same could be said about the Zapatista Women's Revolutionary Laws, who mobilise many tropes and aspirations circulating in globalised rights and feminist discourses, such as the right to use contraception and the right to own and inherit means of economic production, a major issue in patriarchal peasant societies. These claims for land, education, health, security, identity, political agency and other individual and collective rights do not, however, constitute the kind of blueprint provided by literary utopias. Theses discourses are usually very careful to put emphasis on preserving possibilities rather than on prescriptive statements about how one should live or act, about what the good life actually should look like. This precaution springs from the anti-authoritarian principles that motivate these movements. However, regarding the use of the concept of utopia in anthropological work, it is worth noting that the empirical examples considered above indicate that further nuances are in order. Even though I have begun this paper by distinguishing between the utopian impulse and literary utopias, as others have done before me, the examples considered here indicate that the utopian impulse to "break" with an existing order of things is hardly ever made without at least some reference to tropes, narratives and envisioned alternatives, even though care is taken not to transform these references into rigid and too specific political programs.

21 If this observation is made to bear more directly on comparative anthropological work, it appears that most attention is paid to the negative tropes and narratives, the description of conditions, ideas and situations that are detrimental to the ethnographic subjects' well-being. In fact, much ethnographies that deal with power relations and life conditions in colonial, imperialist or neoliberal contexts produce descriptions of what could be termed "lived dystopias". This seems mostly to be a reflection of the global and local political economy, which has been critical anthropology's main concern over the last several decades. As Darko Suvin writes:

[Capitalism] pretends this is a finally realized eutopia (end of qualitative history) but since it is in fact for about 90 percent of humanity clearly, and for 8-9 percent in subterranean ways, a lived dystopia, [capitalism] demands to be called antidystopia. We live in an ever faster circulation of a whirligig of fads that do not better human relationships but allow heightened oppression and exploitation, especially of women, children, and the poor [...]. (Suvin $2010: 389$ )

Indigenous peoples certainly share this lived dystopia. One of the first and perhaps better-known texts produced by the Zapatista movement eloquently narrates the exploitation endured by Chiapas:

Chiapas loses blood through many veins : Through oil and gas ducts, electric lines, railways, through bank accounts, trucks, vans, boats and planes, through clandestine paths, gaps, and forest trails. This land continues to pay tribute to the imperialists : petroleum, electricity, cattle, money, coffee, banana, honey, corn, cacao, tobacco, sugar, soy, melon, sorghum, mamey, mango, tamarind, avocado, and Chiapaneco blood flows as a result of the thousand teeth sunk into the throat of the 
Mexican Southeast. These raw materials, thousands of millions of tons of them, flow to Mexican ports and railroads, air and truck transportation centers. From there they are sent to different parts of the world: The United States, Canada, Holland, Germany, Italy, Japan, but with the same fate-to feed imperialism. The fee that capitalism imposes on the Southeastern part of this country oozes, as it has since from the beginning, blood and mud. (EZLN 1994 : 1)

A more generalised statement of the lived dystopia experienced by Indigenous peoples was proposed by Mexican anthropologist Rodolfo Stavenhagen, UN Special Rapporteur on the situation of human rights and fundamental freedom of Indigenous peoples from 2001 to 2008. He frames the commonalities between highly diverse Indigenous societies and cultures in terms of a "shared historical experience" (1999). Stavenhagen refers implicitly to the concept of "situation" that was introduced to social anthropology by the works of Franz Fanon and George Balandier as a tool to think about the "colonial situation". As one might imagine, the characteristics of this Indigenous shared historical experience have a strong family resemblance with the dystopian colonial situation.

The idea of a "shared situation" facilitated the development of international tools for the definition and affirmation of Indigenous peoples' rights. Significant political parallels and alliances were conceptually made possible by referring to a common "Indigenous World", an idea most prominently put forward by the International Work Group for Indigenous Affairs (IWGIA), and by advocating common Indigenous rights as in the UN Declaration on the Rights of Indigenous Peoples. The notion of a shared Indigenous situation has also proven interesting in the context of comparative anthropological work, in particular in comparing how Indigeneity is produced in different national contexts. Accordingly the notion of "Indigeneity" as a shared situation contributes to break the isolation of groups that have experienced violent regional, national and global structures being forced upon them by the formation of colonies, markets, states and nations.

As the colonial situation, the Indigenous situation and, one could add, the neoliberal situation, are concepts that build comparative bridges between various contexts with similar articulations with the global political economy. However, they also have the weakness of their strengths. By bringing to the fore the violence inherent in these historical situations, the description of Modernity's dystopias, and the strategies of resistance against them, provided powerful points of convergence for anti-hegemonic political and intellectual projects. Post-colonial, subaltern, decolonial and other critical theories developed key concepts to examine the world system, and had concrete relevance to action and analysis. But at their core lies the image of the suffering subjects. The urgency and imperative of speaking truth to power as well as the fact that, as Suvin points out, disenfranchisement might be the lot of the vast majority of subjects within the capitalist project certainly warrants critical anthropology's efforts to take the "pathologies of power" (Farmer 2004) as an important starting point of their analyses. At the root of the "shared historical experience" of Indigenous peoples outlined by Stavenhagen is mostly suffering, trauma, violence and exclusion.

Joel Robbins (2013) points out that since the mid-1980s anthropology has had the tendency to focus perhaps a little too exclusively on this empirical and theoretical starting point. He argues that as the idea of the quintessential "exotic subject" became less and less tenable within the discipline during the second half of the Twentieth Century, anthropology turned to the "suffering subject" as the centrepiece of its ethnographic and comparative work. In itself, this turn allowed for significant and important critical contributions, producing detailed accounts of structural violence and 
testimonies of subaltern suffering. But after decades of such comparative work, a need came up for a complementary and robust ethnographic engagement with Mannheim's "situationally transcendent" ideas and practices beyond the notions of critique and resistance. Of course, critical analysis of violence and the ethnography of hopes and aspirations are not mutually exclusive. In fact, they are entwined in many ways. As David Graeber puts it:

[...] all forms of systemic violence are (among other things) assaults on the role of the imagination as a political principle, and the only way to begin to think about eliminating systemic violence is by recognizing this. (Graeber 2004)

However, the study of political imagination requires its own research programme, a programme that takes into account the detrimental effects of violence without being subsumed under an anthropology of domination and resistance that is only understandable as a response to this domination. Robbins has proposed to name the comparison of desired and desirable worlds "anthropology of good". Similarly, Dan Chodorkoff (2014) called for a "reconstructive anthropology", which he calls an "anthropology of utopia", to examine the production and experience of alternative political projects. I have proposed elsewhere that we explore the possibility of developing an "anthropology of peace", elucidating through fieldwork the conditions and socially defined substantial contents of what Johan Galtung (1969) has termed "positive peace" on different scales (Hébert 2006). Vincent Crapanzano (2003) prefers to speak of an anthropology of "imaginative horizons" centred on subjective apprehensions of possibility. Suvin, who played a key role in the revival of interest in utopia as a concept relevant to social analysis in the 1970s, drew from the existentialist tradition for which the concept of situation was central. He proposed that we should balance out the "trop plein", the overdetermination, of violent social and historical situations with, as he says paraphrasing Jean-Paul Sartre, what is "defined by a hollow", namely hope, utopian projects and freedom.

28 I could go on giving examples of anthropologists who have called for taking into account hope as a central concern of ethnography in recent years (Miyazaki 2004; Anderson 2006; Demant Frederiksen 2007; Fox 2015), but a picture is already emerging from these few calls to ally critique with utopianism: authors that have been quite occupied with the study of violent situations, and the socio-historical Indigenous situation is certainly one of them, become more and more preoccupied with complementing their critical project with systematic, rigorous, empirical study of how people produce and envision possibilities for moving beyond these situations. Perhaps the most appropriate name for this intellectual and political project is the "anthropology of hope" proposed by August Carbonella (2003), which seeks to combine many aspects mentioned by the authors just cited - authors who, unfortunately, have a tendency to develop parallel projects rather than building on the growing number of contributions based on this perspective. Although Carbonella does not provide more syntheses than the other authors I referred to, he nevertheless identifies a number of ideas that do have the potential to further the rehabilitation of utopianism within anthropological theory. Like others, and mostly on the basis of David Harvey's work, he reasserts the importance of future-oriented research, with an empirical emphasis on political imagination and the ethnography of emerging possibilities. Carbonella also keeps strong ties to the materialist tradition by locating these hopes within a historical situation, calling for an institutional and politicaleconomical analysis of the context in which possibilities exist. In this sense, and very much in the tradition of Bloch's materialist articulation of the utopian imagination, the 
anthropology of hope would focus directly on the "use value of social dreaming", as Moylan and Baccolini (2007) have termed it in an important volume on contemporary utopianism. This anthropology of hope re-centres the methodology of the social sciences around positive normativity, the "anthropology of the good" demanded by Robbins, around the understanding of political projects as autonomous aspirations that are not primarily defined in an oppositional manner as being against something. This project of an anthropology of hope also has the potential to take the utopian strain of the social sciences seriously, to recognise their own engagement with the production of possibilities within their own social-historical context (Levitas 2013).

Graeber (2004) has identified two important methodological implications of this intellectual and political project. The first one is ethnographic in the sense that its purpose is to document hopes, political alternatives and many forms of social imagination encountered in the field. It deals with the dialogical understanding of life projects and political projects, of political possibilities as they emerge and are articulated. Graeber also concurs with Levitas in arguing that ethnography does more than merely document political alternatives. It is entwined with a second aspect of anthropological work, which he calls the "utopian" moment of anthropology and critical theory in general. This moment complements the eliciting of the hopes and social dreams of "Others", and involves bringing our own visions of the "good" to the discussion. It is a theoretically distinct, but perhaps temporally concomitant moment of political engagement when the anthropologist participates in the utopian project, and in potential bridges across contexts.

These proposals for the development of an anthropology of hope echo dialogues between researchers and their partners in the field. In various contexts, the need to move beyond a discourse of victimhood has been noted (Marlowe 2010), even when engaging with people living in extremely dire circumstances. In Chiapas since the mid-1990's, we certainly see a strong intention to eschew fatalism and build a political community based on the project to bring about new political worlds that would constitute a global alternative to neoliberal hegemony. This utopian impulse was perhaps stated most plainly in the Zapatistas' First declaration of La Realidad in January 1996. This document is a broad call for the reinvigoration of utopianism. As I noted above, it does not short-circuit critique, but rather intends to build on it. Critique of the violent social order is a premise, an invitation to go beyond it:

The new distribution of the world excludes "minorities". The indigenous, youth, women, homosexuals, lesbians, people of color, immigrants, workers, peasants ; the majority who make up the world basements are presented, for power, as disposable. The new distribution of the world excludes the majorities.

[...]

Instead of humanity, [globalisation] offers us stock market value indexes, instead of dignity it offers us globalisation of misery, instead of hope it offers us an emptiness, instead of life it offers us the international of terror.

Against the international of terror representing neoliberalism, we must raise the international of hope.

Hope, above borders, languages, colors, cultures, sexes, strategies, and thoughts, of all those who prefer humanity alive.

The international of hope. Not the bureaucracy of hope, not the opposite image and, thus, the same as that which annihilates us. Not the power with a new sign or new clothing. A breath like this, the breath of dignity. (EZLN 1996) 
Even though this call for the creation of an "International of hope" was made twenty years ago, it still demonstrates that the renewed interest in utopianism I have documented in this last section is not exclusively a product of social theory's closed confines. The context of Chiapas, in itself, gives us many examples of this renewed utopian impulse in concrete social practices, from the declaration of La Realidad to the formation of lived alternative communities called Caracoles and Juntas de buen gobierno in 2003. Try to summarise the expression of contemporary utopian imagination in other parts of Latin America since then (especially the discussions around the principle of buen vivir in Bolivia) would go far beyond the scope of this article. However, what should stand out from this section is that for the last two decades both social theory and political practice have called on anthropological theory to take utopianism more seriously. Although the mapping I have tried to provide indicates that anthropological work tended to recognise hope as a productive concept for comparative work, it seems that we have yet to establish a strong dialogue with the rich scholarship and praxis of utopia today.

\section{Conclusion}

To examine some contributions of utopia to contemporary anthropological work, I drew on material from the early years of the Zapatista movement, mostly because it reveals an interesting chronological parallel with a period in which the interest in utopian theory within the social sciences increased significantly. After the lull created by the collapse of numerous socialist experiences at the end of the 1980s, it seemed, during the mid-1990s, that utopian imagination was gaining momentum once again both in analytical and political work. By taking that period as a point of reference, I argued that despite the continuing triumphalist discourse of capitalism, neoliberal globalisation and developmentalism, the need for what Mannheim called situationally transcendent ideas and practices becomes more and more visible.

33 I have outlined a number of reasons explaining why political anthropology, although it paid attention to hope during that period, remained reluctant to engage significantly with the concept of utopia. But as I tried to demonstrate, this concept serves as a very powerful complement to more locally grounded life projects. Referring back to Mannheim's discussion of utopianism as an embodied production of anti-ideological cognitive schemes and Ernst Bloch's conceptualisation of utopian imagination as a yearning driving change, it seems that utopia has a place within the conceptual toolbox we employ to understand political projects. Since utopia refers to worlds "not yet in being", it adds dimensionality to anthropology's traditional preoccupation with the encounter of existing cultural worlds. The Zapatistas' call for the creation of an "International of Hope" contained this impulse to create something new. Utopianism is not just about hoping for this novum, it is also about producing it within a given sociohistorical situation. It is through this inscription in place and history that utopianism can become an object of ethnography. It is also perhaps through this empirical engagement with hope that anthropologists can begin to come to terms with the utopianism at the core of their own discipline. 


\section{BIBLIOGRAPHY}

Abensour, Miguel, 2013, L'homme est un animal utopique. Paris: Sens \& Tonka.

Anderson, Ben, 2006, "“Transcending Without Transcendence": Utopianism and an Ethos of

Hope". Antipode. 38 (4): 691-710.

Ansart, Pierre, 1977, Idéologies, conflits et pouvoir. Paris: Presses Universitaires de France.

Balandier, George, 1951, "La situation coloniale: approche théorique" Cahiers internationaux de

sociologie, vol. 11, pp. 44-79.

Bentham, Jeremy, 1827, Rationale of Judicial Evidence. vol. IV. London: Hunt and Clarke.

Berquist Soule, 2004, The Bishop's Utopia. Envisioning Improvement in Peru. Philadelphia: University of Pennsylvania Press.

Blaser, Mario, 2013, "Ontological Conflicts and the Stories of Peoples in Spite of Europe: Toward a Conversation on Political Ontology" Current Anthropology, vol. 54, no.5, pp. 547-568.

Blaser, Mario, Harvey A. Feit and Glenn McRae, Eds., 2004, In the Way of Development. Indigenous Peoples, Life Projects and Globalization, London, Zed Books.

Blaser, Mario, 2004, "Life Projects: Indigenous Peoples' Agency and Development" pp. 26-46 in In the Way of Development. Indigenous Peoples, Life Projects and Globalization (M. Blaser, H.A. Feit, and G. McRae, Eds.) London, Zed Books.

Bloch, Ernst, 1964 [1921], Thomas Münzer, théologien de la révolution. Paris: Julliard.

Bloch, Ernst, 1995 [1939], The Principle Hope, vol. 1, Cambridge, Mass.: MIT Press.

Buckley and Violeau, 2011, Utopie. Texts and Projects, 1967-1978. Los Angeles: Semiotext(e).

Carbonella, August, 2003, "Towards an Anthropology of Hope" Focaal, Journal of Global and Historical Anthropology, no.42, pp. 173-186.

Chodorkoff, Daniel, 2014, The Anthropology of Utopia. Porsgrunn: New Compass Press.

Cooper, Davina, 2014, Everyday Utopias. The Conceptual Life of Promising Spaces. Durham, NC: Duke University Press.

Crapanzano, Vincent, 2003, Imaginative Horizons: An Essay in Literary-Philosophical Anthropology. Chicago: University of Chicago Press.

Delanoi, 1990, Les années utopique, 1968-1978. Paris: La découverte.

Demant Frederiksen, Martin, 2007, Futures in the making: hope among youth in Tbilisi. Århus: Department of Anthropology and Ethnography, Aarhus University.

Dermenghem, Émile, 1927, Thomas Morus et les utopistes du la Renaissance. Paris: Plon.

Doren, Alfred, 1927, “Wunschräume und Wunschzeiten” pp. 158-205 in Vorträge der Bibliothek Warburg 1924-1925 (Fritz Saxl, Ed.), Leipzig, Berlin.

Dumont, René, 1973, L’utopie ou la mort. Paris: Seuil. 
EZLN, 1994, The Southeast in Two Winds a Storm and a Prophecy. Accessed online at http:// schoolsforchiapas.org/wp-content/uploads/2014/03/The-Southeast-in-Two-Winds-A-Stormand-a-Prophecy.pdf, November $20^{\text {th }} 2015$.

EZLN, 1996, The First Declaration of La Realidad. Accessed online at www.schoolsforchiapas.org/ library/1st-declaration-la-realidad-humanity-neoliberalism, November $20^{\text {th }} 2015$.

Engels, Friedrich, 1908 [1880], Socialism, Utopian and Scientific. Chicago: Charles H. Kerr \& Company.

Escobar, Arturo, 2008, Territories of Difference. Place, Movements, Life, Redes. Durham: Duke University Press.

Farmer, Paul, 2004, Pathologies of Power. Health, Human Rights, and the New War on the Poor. Berkeley: University of California Press (Revised edition).

Firestone, Clark B., 1924, The Coasts of Illusion; A Study of Travel Tales. New York: Harper \& Brothers. Foro Social de los Montes Azules, 2010, Declaración del Foro Social de los Montes Azules. Accessed online at: https://chiapaspaz.wordpress.com/2010/03/06/declaracion-del-foro-social-de\%C2\% A0los\%C2\%A0montes\%C2\%A0azules/, July 312015.

Fox, Elizabeth, 2015, "Making cashmere, making futures: The work of hope and the materialisation of dreams in a mongolian cashmere factory". Inner Asia. 17 (1): 77-99.

Fukuyama, Francis, 1992, The End of History and the Last Man, New York: The Free Press.

Fuller, Buckminster, 1969, Utopia or Oblivion: The Prospects for Humanity. Woodstock, NY: Overlook. García de León, Antonio, 1985, Resistencia y utopia. Mexico: Ediciones ERA. 2 Volumes.

García Quintanilla, Alejandra, 1994, “Aguascalientes 1994: la utopia recuperada” pp. 175-178 in A proposito de la insurgencia en Chiapas. (Silvia Hernádez, Ed.) Mexico: Asociación para el Desarrollo de la Investigación Científica y Humanística en Chiapas.

Gingrich, André and Richard Gabriel Fox, 2002, Anthropology, by Comparison. London; New York: Routledge.

Goodwin, Barbara and Keith Taylor, 2009 [1982], The Politics of Utopia. A Study in Theory and Practice. Oxford: Peter Lang.

Gossen, Gary H., 1999, Telling Maya Tales. Tzotzil Identities in Modern Mexico. New York: Routledge.

Graeber, David, 2004, Fragments for an Anarchist Anthropology. Chicago: Prickly Paradigm Press.

Green, Toby, 2004, Thomas More's Magician, A Novel Account of Utopia in Mexico. London: Weidenfeld \& Nicolson.

Habermas, Jürgen, 2010, “The Concept of Human Dignity and the Realistic Utopia of Human Rights” Metaphilosophy, vol. 41, No.4, pp. 464-480.

Harvey, David, 2000, Spaces of Hope. Berkeley: University of California Press.

Hébert, Martin, 2012, “Chiapas, un virage à gauche regional?" pp. 205-222 in L'interpellation plébéienne en Amérique latine. Violence, actions directes et virage à gauche. Paris, Montréal: Karthala, Presses de l'Université du Québec.

Hébert, Martin, 2006, "Présentation: paix, violences, anthropologie" Anthropologie et societies, vol. 30, No.1, pp. 7-28.

Hébert, Martin, 2001, Sous le regard des ancêtres. Conflit et coopération chez les Tlapanèques $d u$ Guerrero. Université de Montréal, Department of Anthropology, Ph.D. Thesis. 
Hernández Castillo, Rosalva Aída, 1999, “Construyendo la utopía: esperanzas y desafíos de las mujeres chiapanecas de frente al siglo XXI" pp. 482-494-142 in Las alzadas (Sara Lovera and Nellys Palomo, Ed.) Mexico: Comunicación e Información de la Mujer, A.C. y Convergencia Socialista, A.P.N.

Hertzler, Joyce Oramel, 1923, The History of Utopian Thought. New York: Macmilan. Jameson, Fredric, 2005, Archaeologies of the Future. London: Verso.

Khasnabish, Alex, 2008, Zapatismo Beyond Borders. New Imaginations of Political Possibilities. Toronto: University of Toronto Press.

Laclau, Ernesto, 1996, Emancipation(s). London: Verso.

Legorreta Díaz, Maria del Carmen, 1998, Religión, políticay guerrilla en Las Cañadas de la Selva Lacandona. Mexico, D.F.: Cal y Arena.

Levitas, Ruth, 2013, Utopia as Method: The Imaginary Reconstruction of Society. New York: Palgrave Macmillan.

Lockyer, Joshua and James R. Veteto, Ed., 2013, Environmental Anthropology Engaging Ecotopia. Bioregionalism, Permaculture, and Ecovillages. Oxford: Berghann.

López Monjardín, Adrianna, 1998, “En busca de una utopía democrática” pp. 105-107 in Acuerdos de San Andrés. (Luis Hernández and Ramón Vera Herrera, Ed.) Mexico: Ediciones ERA.

Love Brown, Susan, Ed., 2001, Intentional Community: An Anthropological Perspective. New York: SUNY Press.

Löwy, Michael, 1996, "Présentation", pp. 8-5 in Utopie. Théologie de la libération, philosophie de l'émancipation. Paris: Presses Universitaires de France.

Mannheim, Karl, 1985 [1936], Ideology and Utopia. San Diego: Harcourt Brace \& Co.

Marcus, George E. and Michael M. J. Fischer, 1986, Anthropology as Cultural Critique. Chicago: University of Chicago Press.

Marder, Michael and Patrícia Vieira, 2011, Existential Utopia: Of the World, the Possible, the Finite » pp. 35-49 in Existential Utopia: New Perspectives on Utopian Thought (M. Marder and P. Vieira, Eds.) New York: Bloomsbury Publishing.

Marlowe, Jay M., 2010, "Beyond the Discourse of Trauma: Shifting the Focus on Sudanese Refugees" Refugee Studies, vol. 23, no.2, pp. 183-198.

Marouby, Christhian, 1990, Utopie et primitivisme. Essai sur l'imaginaire anthropologique à l'âge classique. Paris: Seuil.

Meunier, Jacques, 1992, "Fictions et mythes ethnologiques" pp. 278-280 in Dictionnaire de l'ethnologie et de l'anthropologie (P. Bonte and M. Izard, Eds.) Paris: Presses Universitaires de France.

Miranda Ocampo, Raúl, Ed., 1995, Chiapas, el regreso a la utopía. Mexico: Universidad Autónoma de Guerrero' Editorial Comuna.

Miyazaki, Hirokazu, 2004, The Method of Hope: Anthropology, Philosophy, and Fijian Knowledge. Stanford: Stanford University Press.

Montesano Montessori, Nicolina, 2011, "The Design of a Theoretical, Methodological, Analytical Framework to Analyse Hegemony in Discourse" Critical Discourse Studies, vol. 8, No.3: 169-181. 
Mouterde, Pierre, 2002, Quand l'utopie ne désarme pas. Les pratiques alternatives de la gauche latinoaméricaine. Montréal: Écosociété.

Moylan, Tom, 1986, Demand the impossible. Science Fiction and the Utopian Imagination. Oxford: Peter Lang.

Moylan, Tom and Raffaella Baccolini, Eds., 2007, Utopia Method Vicion: The Use Value of Social Dreaming. Oxford: Peter Lang.

Moyn, Samuel, 2012, The Last Utopia. Human Rights in History. Cambridge, MA: Harvard University Press.

Nader, Laura, 1991, Harmony Ideology. Justice and Control in a Zapotec Mountain Village. Stanford: Stanford University Press.

Nash, June, 1971, In the Eyes of the Ancestors: Belief and Behavior in a Mayan Community. New Haven: Yale University Press.

Ochoa, John, 2013, "Professors on the Run: How Marco's Narratives of Zapatismo Refashion North American Cold War Anxiety" Comparative American Studies, vol. 11, No.1, pp. 52-73.

Olin Wright, Erik, 2010, Envisioning Real Utopias. London: Verso.

Price, Charles, Donald Nonini, and Erich Fox Tree, 2008, "Grounded Utopian Movements: Subjects of Neglect". Anthropological Quarterly. 81 (1): 127-159.

Raulet, Gérard, 1992, “L’utopie est-elle un concept?” Lignes, No.17, pp. 102-107.

Rhiannon, Evans, 1999, "Ethnography's Freak Show. The Grotesque at the End of the Roman Empire" Ramus. 28 (1): 54-73.

Ricoeur, Paul, 1986, Lectures on Ideology and Utopia. New York: Columbia University Press.

Robbins, Joel, 2013, "Beyond the Suffering Subject: Toward an Anthropology of the Good" Journal of the Royal Anthropological Institute. (N.S.) 19, pp. 447-462.

Rubiés, Joan-Pau, 2007, Travellers and Cosmographers. Studies in the History of Early Modern Travel and Ethnology. Surrey, UK: Ashgate Publishing.

Russ, Jan et al., 2003, Mayan Lives, Mayan Utopias. Lanham, MD: Rowan and Littlefield.

Sargent, Lyman Tower, 1979, British and American Utopian Literature, 1516-1975.Boston: G.K. Hall \& Co.

Saumier, Genevière, 2001, "Les lois révolutionnaires des femmes au sein du zapatisme" Recherches amérindiennes au Québec, vol. 31, No.1, pp. 71-82.

Servier, Jean, 1991, Histoire de l'utopie. Paris: Gallimard.

Spiro, Melford E., 1957, "Kibbutz: Venture in Utopia.". Man. 57: 159-160.

Spiro, Melford E., 2004, "Utopia and Its Discontents: The Kibbutz and Its Historical Vicissitudes". American Anthropologist. 106 (3): 556-568.

Stavenhagen, Rodolofo, 1999, La cuestion étnica. Mexico, D.F., Colegio de México.

Stewart, Julian H. et al., 1956, The People of Puerto Rico: A Study in Social Anthropology. Urbana: University of Illinois Press.

Uhlenbruch, Frauke, 2015, The Nowhere Bible. Utopia, Dystopia, Science Fiction. Berlin: Walter de Gruyter. 
Wallerstein, Immanuel, 1998, Utopistics Or, Historical Choices of the Twenty-First Century. New York: The Free Press.

\section{ABSTRACTS}

In this article, I discuss potential contributions of the concepts of utopia and utopianism to contemporary anthropological theory. Taking Indigenous politics in the state of Chiapas, Mexico, as an empirical backdrop, our exploration begins by situating the meaning of these concepts by examining some aspects of utopian theory as it has developed outside anthropology. In particular, I look at how Karl Mannheim understood the notion of utopia in the 1920s, arguing that his juxtaposition of utopia and ideology can be productive for political anthropology. After addressing some of the reasons why anthropological theory has been reluctant to incorporate the concept of utopia, a reluctance often related to the concept's modernist and Western connotations, I argue that utopia should be understood as a transformative impulse rather than a specific content or blueprint that outlines a desired social order. By examining how this utopian impulse manifested itself during the first years of the Zapatista movement on various levels from the community to the global civil society, I content that the concept of utopia can make at least two contributions to today's anthropological theory. First, it can help analysing broad movements that mobilise a wide variety of actors. I look at examples from Chiapas and conclude that the Zapatistas' call for the creation of an "International of Hope", articulating diverse "life projects" into a larger, anti-hegemonic political project, can be interpreted in a productive way through the lens of utopianism. The concept's second contribution to comparative anthropological work goes back to Mannheim's idea that utopias are "situationally transcendent" ideas and practices. While anthropology actively studies encounters between different worlds within the confines of a given social-historical situation, it is less attentive to possibilities and worlds "not yet in being". In closing, I argue that a deeper consideration of utopianism within the context of anthropological debates can make a significant contribution to moving critical anthropology's focus from the suffering subject to the hoping subject, a project that scholars and activists have long demanded.

Dans cet article, je discute la contribution potentielle des concepts d'utopie et d'utopisme à la théorie anthropologique contemporaine. En prenant la politique indigène au sein de l'état du Chiapas (Mexique) comme ancrage empirique, notre exploration commence par situer le sens de ces concepts, en examinant quelques aspects de la théorie utopique telle qu'elle s'est développée hors du champ de l'anthropologie. Je regarde en particulier la manière dont Karl Mannheim a compris la notion d'utopie dans les années 1920, et je soutiens que sa juxtaposition entre utopie et idéologie peut être productive pour l'anthropologie politique. Après avoir analysé certaines des raisons pour lesquelles la théorie anthropologique a été rétive à incorporer le concept d'utopie, une réticence souvent liée aux connotations occidentales et modernistes du concept, je soutiens que l'utopie doit être comprise comme une impulsion transformatrice plus que comme un contenu spécifique ou un plan dessinant un ordre social désirable. En examinant la manière dont cette impulsion utopique s'est manifestée durant les premières années du mouvement zapatiste, à différents niveaux allant de la communauté à la société civile globale, j'affirme que le concept d'utopie peut apporter au moins deux contributions à la théorie anthropologique actuelle. Premièrement, il peut aider à analyser de larges mouvements qui mobilisent une grande variété d'acteurs. Je considère des exemples au Chiapas et j'en conclus qu'il est judicieux d'interpréter dans la perspective de l'utopisme l'appel des Zapatistes à la création d'une «Internationale de l'Espoir », articulant différents «projets de vie » dans une projet politique anti-hégémonique plus large. La deuxième contribution du concept à l'anthropologie 
comparative ramène à l'idée de Mannheim selon laquelle les utopie sont des idées et des pratiques qui «transcendent les situations». Alors que l'anthropologie étudie activement les rencontres entre différents mondes dans les limites d'une situation social-historique donnée, elle est moins attentive aux possibilités et aux mondes « qui n'existent pas encore ». Pour conclure, je soutiens qu'une plus grande prise en compte de l'utopisme dans le contexte des débats anthropologiques peut apporter une contribution significative, afin de déplacer la perspective de l'anthropologie critique du sujet souffrant vers le sujet espérant, un projet que chercheurs et activistes appellent de leurs vœux depuis longtemps.

Este artículo trata sobre las posibles contribuciones de los conceptos de utopía y de utopismo a la teoría antropológica contemporánea. Tomando como trasfondo empírico la política indígena en el Estado de Chiapas, México, nuestra exploración comienza situando el significado de estos conceptos examinando algunos aspectos de la teoría utópica tal como se ha desarrollado al exterior de la antropología. En particular, intento observar el modo en el que Karl Mannheim entendió la noción de utopía en la década de 1920, con el argumento según el cual la yuxtaposición de la utopía y la ideología puede ser productiva para la antropología política. Después de abordar algunas de las razones por las cuales la teoría antropológica ha sido reacia a incorporar el concepto de utopía, renuencia a menudo relacionada con el modernismo del concepto y con connotaciones occidentales, mi argumento sostiene que la utopía ha de entenderse mejor como un impulso transformador que como un contenido específico o un modelo que traza un orden social deseado. Al examinar cómo este impulso utópico se manifestó durante los primeros años del movimiento zapatista en varios niveles, que van de la comunidad a la sociedad civil global, sostengo que el concepto de utopía puede realizar al menos dos contribuciones a la teoría antropológica actual. En primer lugar, permitiría analizar los extensos movimientos que movilizan una gran variedad de actores. Observo aquí ejemplos provenientes de Chiapas y concluyo que la llamada de los zapatistas para la creación de una "Internacional de la Esperanza", al articular diversos "proyectos de vida" en un proyecto político ampliado y antihegemónico, se puede interpretar de un modo productivo mediante el prisma del utopismo. La segunda contribución del concepto para un trabajo antropológico comparativo, se remonta a la tesis de Mannheim, según la cual las utopías son ideas y prácticas "situacionalmente trascendentales". Cuando la antropología estudia activamente encuentros entre diferentes mundos dentro de los confines de una situación histórico-social dada, se halla menos atenta a las posibilidades y a los mundos "que aún no existen". Para concluir, señalo que una consideración más profunda del utopismo en el contexto de los debates antropológicos puede generar una contribución significativa para mover el enfoque de la antropología crítica del sujeto sufriente al del sujeto de la esperanza, un proyecto que los especialistas y los activistas han exigido desde hace mucho tiempo.

\section{INDEX}

Mots-clés: Utopisme, espérance, projets politiques, peuples autochtones, Chiapas

Palabras claves: Utopismo, esperanza, proyectos políticos, pueblos indígenas, Chiapas

Keywords: Utopianism, Hope, Political Projects, Indigenous peoples, Chiapas

\section{AUTHOR}

\section{MARTIN HÉBERT}

Département d'anthropologie. Université Laval, Québec, Canada 